\title{
ANALISIS FAKTOR-FAKTOR YANG MEMPENGARUHI MOTIVASI BELAJAR MAHASISWA PROGRAM STUDI S1 MANAJEMEN ANGKATAN 2016 PADA STIE RAHMANIYAH SEKAYU
}

\author{
Usailan Oemar \\ Sekolah Tinggi Ilmu Ekonomi Rahmaniyah \\ Email: elanoemar11@yahoo.com \\ Dadang Syaputra \\ Politeknik Negeri Media Kreatif Jakarta \\ Email: Syaputradadang36@gmail.com
}

\begin{abstract}
ABSTRAK
Penelitian ini menggunakan variabel bebas $(\mathrm{X})$ dan vaiabel bebas $(\mathrm{Y})$ didapatkan hasil yaitu: faktor fisik $\left(\mathrm{X}_{1}\right)$, faktor psikologis $\left(\mathrm{X}_{2}\right)$, dan faktor sosial $\left(\mathrm{X}_{4}\right)$ tidak berpengaruh secara parsial terhadap motivasi belajar karena memiliki nilai $\mathrm{t}$ hitung $<\mathrm{t}$ tabel. Sedangkan faktor non-sosial $\left(\mathrm{X}_{3}\right)$ berpengaruh secara parsial terhadap motivasi belajar dan mempunyai nilai $t$ hitung $>t$ tabel. Namun secara simultan atau bersamasama faktor fisik $\left(\mathrm{X}_{1}\right)$, faktor psikologis $\left(\mathrm{X}_{2}\right)$, faktor non-sosial $\left(\mathrm{X}_{3}\right)$ dan faktor sosial $\left(\mathrm{X}_{4}\right)$ berpengaruh terhadap motivasi belajar (Y) mahasiswa program studi S1 manajemen angkatan 2016 STIE Rahmaniyah Sekayu. Hal ini dibuktikan dari nilai $\mathrm{f}_{\text {hitung }}$ sebesar $7.762>f_{\text {tabel }}$ 2.46. Sesuai dengan rentang interprestasi koefisien korelasi maka dapat dinyatakan bahwa faktor fisik $\left(\mathrm{X}_{1}\right)$, faktor psikologis $\left(\mathrm{X}_{2}\right)$, faktor non-sosial $\left(\mathrm{X}_{3}\right)$ dan faktor sosial $\left(\mathrm{X}_{4}\right)$ memiliki hubungan yang sedang terhadap motivasi belajar (Y) mahasiswa program studi S1 manajemen angkatan 2016 STIE Rahmaniyah Sekayu dibuktikan dari nilai korelasi ganda sebesar 0.500.
\end{abstract}

Kata kunci: fakor fisik, faktor psikologis, faktor non sosial. faktor sosial dan motivasi

\section{PENDAHULUAN}

\section{Latar Belakan Masalah}

Pendidikan memiliki peran penting bagi peningkatan kualitas sumber daya manusia suatu bangsa. Pendidikan merupakan modal bagi suatu bangsa untuk terus maju dan berkembang sesuai dengan tuntutan zaman. Salah satu indikator untuk menilai maju atau tidaknya suatu bangsa dapat dilihat dari tingkat pendidikan masyarakat dinegara tersebut. Indonesia sebagai negara yang berkembang harus lebih menaruh perhatian yang serius dibidang pendidikan. Pendidikan dapat merubah aspek-aspek pada diri seseorang 
dalam proses pembelajaran melalui serangkaian kegiatan misalnya dengan membaca, mengamati, mendengarkan, berbagi pengalaman dan lain sebagainya.

Di dalam lembaga pendidikan terdapat suatu sistem yang terdiri dari input, proses, dan output. Pada jalur pendidikan, keberhasilan tujuan pembelajaran dapat dilihat salah satunya dari output atau hasil belajar mahasiswa. Salah satu faktor terpenting yang dapat mempengaruhi hasil belajar yaitu adanya motivasi dalam belajar. Pada proses belajar siswa memerlukan adanya motivasi sebagai penggerak aktivitas kegiatan didalamnya.

Sardiman (2011: 75) mendefinisikan motivasi sebagai keseluruhan daya penggerak didalam diri siswa yang menimbulkan kegiatan belajar, yang menjamin kelangsungan dari kegiatan belajar dan yang memberikan arah pada kegiatan belajar, sehingga tujuan yang dikehendaki oleh subjek belajar itu dapat tercapai. Motivasi seseorang akan baik, apabila tujuan dalam diri seseorang baik 
konteks belajar maka tujuan dari dalam diri mahasiswa yaitu untuk mendapatkan hasil belajar yang maksimal. Mahasiswa yang memiliki motivasi kuat, akan mempunyai banyak energi dan semangat untuk mengikuti aktivitas belajar. Motivasi dari lingkungan dapat timbul karena mahasiswa melihat atau mengamati orang lain yang dapat memberikan inspirasi bagi hidupnya, sehingga mahasiswa tertantang untuk dapat melakukan proses belajar yang lebih baik. Pada kegiatan pembelajaran, dosen sering dihadapkan dengan karakteristik mahasiswa yang memiliki motivasi belajar beraneka ragam. Motivasi belajar dalam diri mahasiswa seringkali tidak sama dan juga tidak tetap.

Rendahnya motivasi belajar mahasiswa sering dianggap sebagai penyebab rendahnya kualitas lulusan sebuah perguruan tinggi. Pada kebanyakan perguruan tinggi swasta, faktor ini bahkan menimbulkan persoalan dilematis, karena dengan rendahnya motivasi belajar, sebenarnya tidak mungkin mahasiswa dapat menguasai bahan pembelajaran dengan baik, namun harus diluluskan demi kelangsungan perguruan tinggi tersebut. Praktik seperti ini menjadi aman dan langgeng, karena secara tidak langsung didukung oleh kebanyakan mahasiswa yang tujuan utamanya hanya sekedar untuk memperoleh gelar kesarjanaan saja, dan bukan untuk menguasai ilmu pengetahuan. Sementara, banyak perguruan tinggi yang salah kaprah dalam menerapkan konsep kepuasan pelanggan dalam dunia pendidikan, sehingga memudahkan mahasiswa lulus dianggap sebagai memberikan kepuasan terhadap konsumennya (mahasiswa).

Menurut Yusuf (2009: 23) factor yang mempengaruhi motivasi belajar terbagi menjadi dua yaitu faktor internal yang meliputi faktor fisik dan faktor psikologis. Kemudian faktor eksternal yang meliputi faktor non-sosial dan faktor sosial, yang mana faktor fisik merupakan faktor yang mempengaruhi dari tubuh dan penampilan individu. faktor fisik meliputi nutrisi (gizi), kesehatan, dan fungsi-fungsi fisik terutama panca indera. Faktor psikologis merupakan faktor intrinsik yang berhubungan dengan aspek-aspek yang mendorong atau menghambat aktivitas belajar pada siswa. Faktor ini menyangkut kondisi rohani siswa. Faktor non-sosial merupakan faktor yang berasal dari keadaan atau kondisi fisik disekitar siswa. Faktor non-sosial meliputi keadaan udara (cuaca panas atau dingin), waktu (pagi, siang, atau malam), tempat (sepi, bising, atau kualitas sekolah tempat belajar), dan fasilitas belajar (sarana dan prasarana). Sedangkan factor social merupakan faktor yang berasal dari manusia disekitar lingkungan siswa. Faktor social meliputi guru/dosen, konselor, teman sebaya, orang tua, tetangga, dan lain-lain.

Dapat dikatakan bahwa motivasi belajar mahasiswa merupakan faktor yang paling menentukan dalam menciptakan sarjana atau sumber daya manusia yang berkualitas. Sehingga sejalan dengan tekad sekolah tinggi ilmu ekonomi rahmaniyah yang merupakan lembaga pendidikan yang berdiri dibawah naungan yayasan rahmany dan memiliki tujuan untuk menghasilkan sarjana yang berkualitas. sehingga mampu bersaing dipasar kerja dan menjadi penggerak pembangunan serta pemberdayaan ekonomi secara nasional, tekad itu kiranya dibarengi dengan upaya untuk meningkatkan motivasi belajar mahasiswanya, namun dalam hal ini Sekolah 
Tinggi Ilmu Ekonomi Rahmaniyah Sekayu masih mengalami kendala dalam meningkatkan motivasi belajar para mahasiswanya yang mana dapat dilihat dari masih adanya beberapa mahasiswa yang tidak menjawab pertanyaan yang diberikan oleh dosen, sibuk berbicara dengan teman-temannya, bermain handphone dalam proses pembelajaran, menurunnya rata-rata nilai semester mahasiswa dan banyaknya mahasiswa yang mendapatkan nilai "C". Motivasi belajar mahasiswa sekolah tinggi ilmu ekonomi rahmaniyah diharapkan dapat meningkat demi mempermudah terwujudnya tujuan organisasi.

Berdasarkan uraian latar belakang masalah diatas maka peneliti tertarik untuk mengadakan penelitian dengan judul "ANALISIS FAKTOR-FAKTOR YANG MEMPENGARUHI MOTIVASI BELAJAR MAHASISWA PROGRAM STUDI S1 MANAJEMEN ANGKATAN 2016 PADA STIE RAHMANIYAH SEKAYU".

\section{I.1. Rumusan Masalah}

Berdasarkan uraian sebelumnya pada latar belakang masalah di atas, maka pokok-pokok masalah yang akan dibahas dalam penelitian ini yaitu bagaimana faktor fisik, faktor psikologis, faktor non-sosial dan faktor sosial mempengaruhi motivasi belajar mahasiswa program studi S1 Manajemen angkatan 2016 pada STIE Rahmaniyah Sekayu

\section{I.1.1. Tujuan Penelitian}

Adapun tujuan dari dilakukannya penelitian ini yaitu untuk mengetahui:

1. Pengaruh faktor fisik terhadap motivasi belajar mahasiswa program studi S-1 manajemen angkatan 2016 pada STIE Rahmaniyah Sekayu.

2. Pengaruh faktor psikologis terhadap motivasi belajar mahasiswa program studi S-1 manajemen angkatan 2016 pada STIE Rahmaniyah Sekayu.

3. Pengaruh faktor non-sosial terhadap motivasi belajar mahasiswa program studi S-1 manajemen angkatan 2016 pada STIE Rahmaniyah Sekayu.

4. Pengaruh faktor sosial terhadap motivasi belajar mahasiswa program studi S-1 manajemen angkatan 2016 pada STIE Rahmaniyah Sekayu.

5. Pengaruh faktor fisik, faktor psikologis, faktor non-sosial dan faktor sosial terhadap motivasi belajar mahasiswa program studi S-1 Manajemen angkatan 2016 pada STIE Rahmaniyah Sekayu.

\section{TINJAUAN PUSTAKA}

\section{Pengertian Motivasi Belajar}

Sutrisno (2013: 109) mengemukakan motivasi adalah "faktor yang mendorong seseorang untuk melakukan suatu aktivitas tertentu, motivasi sering kali diartikan pula sebagai faktor pendorong perilaku seseorang”. Mangkunegara (2012: 61) juga mengemukakan motivasi adalah 
"kondisi atau energi yang menggerakkan diri karyawan yang terarah atau tertuju untuk mencapai tujuan organisasi perusahaan".

Hasibuan (2011: 141) meendefinisikan motivasi berasal dari kata Latin movere yang berarti dorongan atau menggerakkan. Motivasi (motivation) dalam manajemen hanya ditujukan pada sumber daya manusia umumnya dan bawahan khususnya. Motivasi mempersoalkan bagaimana caranya mengarahkan daya dan potensi bawahan, agar mau bekerja sama secara produktif berhasil mencapai dan mewujudkan tujuan yang telah ditentukan. Motivasi adalah "hal yang menyebabkan, menyalurkan dan mendukung perilaku manusia, supaya mau bekerja giat dan antusias mencapai hasil yang optimal".

Sardiman (2011: 75) mendefinisikan motivasi sebagai keseluruhan daya penggerak didalam diri siswa yang menimbulkan kegiatan belajar, yang menjamin kelangsungan dari kegiatan belajar dan yang memberikan arah pada kegiatan belajar, sehingga tujuan yang dikehendaki oleh subjek belajar itu dapat tercapai.

Menurut Hamalik (2001: 27) menegaskan bahwa pengertian belajar adalah modifikasi atau memperteguh kelakuan melalui pengalaman (learning is defined as the modification or strengthening of behaviour through experiencing). Menurut pengertian ini, belajar merupakan suatu proses, suatu kegiatan dan bukan hasil belajar semata. Belajar bukan hanya mengingat, akan tetapi lebih luas dari itu, yakni mengalami sendiri..

\section{Metode Motivasi}

Menurut Hasibuan (2006: 149) ada dua metode motivasi, yaitu sebagai berikut:

a) Motivasi Langsung (Direct Motivation)

Motivasi langsung adalah motivasi (materil dan non materil) yang diberikan secara langsung kepada setiap individu untuk memenuhi kebutuhan serta kepuasannya. Jadi sifatnya khusus, seperti pujian, penghargaan, tunjangan hari raya, dan sebagainya.

b) Motivasi Tak Langsung (Indirect Motivation)

Motivasi tak langsung adalah motivasi yang diberikan hanya merupakan fasilitas-fasilitas yang mendukung serta menunjang gairah kerja, sehingga lebih bersemangat dalam bekerja. Misalnya, mesin-mesin yang baik, ruang kerja yang nyaman, kursi yang empuk, dan sebagainya.

\section{Fungsi Motivasi}

Menurut Djamarah (2000: 156-157) fungsi motivasi dalam belajar adalah sebagai berikut:

1) Motivasi sebagai pendorong perbuatan

Motivasi yang berfungsi sebagai pendorong yaitu motivasi yang akan mempengaruhi sikap apa yang seharusnya anak didik lakukan dalam rangka belajar. Pada awalnya peserta didik tidak memiliki minat untuk belajar, karena ada sesuatu yang akan dipelajari, yang belum dipelajari itu akan mendorong anak didik untuk belajar dalam rangka mencari tahu.

2) Motivasi sebagai penggerak perbuatan 
Dorongan psikologis yang melahirkan sikap adalah kekuatan yang sangat kuat yang kemudian menjelma dalam gerakan psikofisik. Akal pikiran berproses dengan raga, perbuatan dan akal pikiran yang sangat kuat sehingga mengerti betul isi apa yang dipelajari.

3) Motivasi sebagai pengarah perbuatan

Peranan motivasi yang dapat mengarahkan perbuatan anak didik dalam belajar, anak didik yang mempunyai motivasi dapat menyeleksi mana yang harus diperbuat dan mana yang tidak dilakukan, faktor pengarah dalam belajar adalah tujuan belajar itu sendiri.

Berdasarkan pendapat diatas, fungsi motivasi dalam belajar antara lain untuk mendorong, menggerakan dan mengarahkan aktivitas-aktivitas peserta didik dalam belajar sehingga dapat mencapai hasil yang maksimal. Dengan begitu seseorang melakukan suatu usaha yang sungguh-sungguh karena adanya tujuan yang baik.

\section{Indikator Motivasi Belajar}

Menurut Sardiman (2011: 83) motivasi yang terdapat dalam diri siswa itu memiliki indikator sebagai berikut :

1) Tekun menghadapi tugas, yaitu dapat bekerja terus menerus dalam waktu yang lama, tidak berhenti sebelum selesai.

2) Ulet menghadapi kesulitan, yaitu tidak mudah putus asa dalam mengerjakan tugas untuk berprestasi sebaik mungkin.

3) Menunjukan minat terhadap macam-macam masalah, misalnya kritis terhadap masalah pembangunan, agama, politik, ekonomi yang terjadi disekitar.

4) Lebih senang bekerja mandiri, lebih menyukai untuk mengerjakan tugas sendiri tidak melihat jawaban teman.

5) Cepat bosan pada tugas-tugas yang rutin, hal-hal yang bersifat berulang-ulang kurang disukai karena tidak mengasah kreatifitas.

6) Dapat mempertahankan pendapatnya

7) Tidak mudah melepaskan hal-hal yang diyakini itu

8) Senang mencari dan memecahkan masalah soal-soal.

\section{Faktor-Faktor Yang Mempengaruhi Motivasi Belajar}

Menurut Yusuf (2009: 23) motivasi belajar dapat timbul karena faktor internal dan eksternal:

1) Faktor internal

a) Faktor Fisik merupakan faktor yang mempengaruhi dari tubuh dan penampilan individu. faktor fisik meliputi nutrisi (gizi), kesehatan, dan fungsi-fungsi fisik terutama panca indera.

b) Faktor Psikologis merupakan factor intrinsik yang berhubungan dengan aspek-aspek yang mendorong atau menghambat aktivitas belajar pada siswa. faktor ini menyangkut kondisi rohani siswa. 
2) Faktor Eksternal

a) Faktor Sosial Merupakan faktor yang berasal dari manusia disekitar lingkungan siswa. Faktor sosial meliputi guru/dosen, konselor, teman sebaya, orang tua, tetangga, dan lain-lain.

b) Faktor Non-sosial merupakan faktor yang berasal dari keadaan atau kondisi fisik disekitar siswa. Faktor non-sosial Meliputi keadaan udara (cuaca panas atau dingin), waktu (pagi, siang, atau malam), tempat (sepi, bising, atau kualitas sekolah tempat belajar), dan fasilitas belajar (sarana dan prasarana).

Menurut Dimyati dan Mudjiono (2010: 97-100) ada beberapa unsur yang mempengaruhi motivasi belajar yaitu :

1) Cita-cita atau aspirasi siswa

Cita-cita dapat berlangsung dalam waktu sangat lama, bahkan sepanjang hayat. Cita-cita siswa untuk "menjadi seseorang" akan memperkuat semangat belajar dan mengarahkan pelaku belajar.

2) Kemampuan Belajar

Kemampuan belajar meliputi beberapa aspek psikis yang terdapat dalam diri siswa. Misalnya pengamatan, perhatian, ingatan, daya pikir, dan fantasi. Di dalam kemampuan belajar ini, sehingga perkembangan berpikir siswa menjadi ukuran. Siswa yang taraf perkembangan berpikirnya konkrit (nyata) tidak sama dengan siswa yang berpikir secara operasioanl (berdasarkan pengamatan yang dikaitkan dengan kemampuan daya nalarnya). Siswa yang mempunyai belajar tinggi, biasanya lebih termotivasi dalam belajar, karena siswa seperti itu lebih sering memperoleh sukses dan karena kesuksesan akan memperkuat motivasinya.

3) Kondisi Jasmani dan Rohani Siswa

Kondisi siswa yang meliputi kondisi jasmani dan rohani dapat mempengaruhi motivasi belajar. Seorang siswa yang sedang sakit, lapar, mengantuk atau kondisi emosional siswa seperti marah-marah akan mengganggu konsentrasi atau perhatian belajar siswa.

4) Kondisi Lingkungan siswa

Lingkungan siswa dapat berupa keadaan alam, lingkungan tempat tinggal atau keluarga, lingkungan pergaulan atau teman sebaya, dan kehidupan masyarakat. Dengan lingkungan yang aman, tentram tertib dan indah maka semangat dan motivasi belajar mudah diperkuat. Lingkungan sosial dapat dibedakan menjadi dua, yaitu lingkungan sosial primer adalah lingkungan sosial dimana tedapat hubungan yang erat dan saling mengenal antara anggota satu dengan anggota yang lain contohnya lingkungan ini yaitu lingkungan keluarga, teman sebaya dan guru. Lingkungan sosial sekunder yaitu lingkungan sosial yang hubungan antar anggota satu dengan anggota yang lainnya agak longgar dan seringnya tidak saling mengenal dengan baik, contohnya lingkungan ini yaitu masyarakat tempat tinggal maupun sekitarnya.

5) Unsur-unsur Dinamis Belajar 
Unsur-unsur dinamis dalam belajar adalah unsur-unsur yang keberadaannya dalam proses belajar yang tidak stabil, kadang lemah dan bahkan hilang sama sekali. Unsur dinamis pada siswa terkait kondisi siwa yang memiliki perhatian, kemauan dan pikiran yang mengalami perubahan berkat pengalaman hidup yang diberikan oleh lingkungan siswa.

6) Upaya Guru/Dosen Membelajarkan Siswa

Upaya yang dimaksud disini adalah bagaimana guru mempersiapkan diri dalam membelajarkan siswa mulai dari penguasaan materi, cara menyampaikannya, menarik perhatian siswa, dan mengatur tata tertib dikelas atau sekolah.

\section{Penelitian Terdahulu}

a. Siswo Martono Sulistiowati (2009).Analisis Faktor-faktor yang mempengaruhi motivasi belajar mahasiswa (Studi kasus di STIKOM Surabaya) STIKOM Surabaya. Hasil penelitian menunjukkan bahwa faktor intrinsik, faktor ekstrinsik berpengaruh signifikan untuk meningkatkan motivasi belajar mahasiswa.

b. Nur Aliah, (2013). Faktor-faktor yang mempengaruhi motivasi belajar mahasiswa diploma kebidanan stikes u'budiyah sigli. StiKes U'Budiyah Banda Aceh. Hasil penelitian menunjukkan bahwa faktor lingkungan, materi dan dosen berpengaruh terhadap motivasi belajar sedangkan, fasilitas tidak berpengaruh terhadap motivasi mahasiswa diploma kebidanan StiKes U'Budiyah Sigli Banda Aceh.

\section{Kerangka Pemikiran}

Sebagai acuan dalam penulisan penelitian ini penulis merumuskan kerangka pemikiran sebagai berikut :

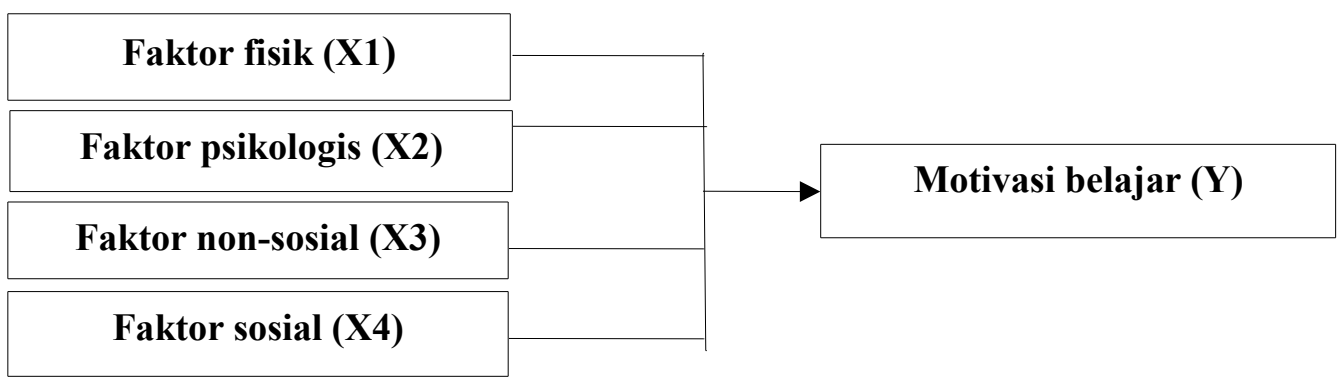

\section{Gambar 1}

\section{Kerangka Pemikiran}

\section{Hipotesis}

Hipotesis penelitian ini adalah jawaban atau dugaan sementara yang harus diuji lagi kebenarannya melalui penelitian ilmiah. Yang menjadi hipotesis dalam peneliti ini adalah Adanya pengaruh yang signifikan antara faktor fisik, faktor psikologis, faktor non-sosial dan faktor sosial terhadap motivasi belajar mahasiswa program studi S1 Manajemen Angkatan 2016 pada 
STIE Rahmaniyah Sekayu.

\section{PROSEDUR PENELITIAN}

\section{Variabel Penelitian}

Adapun variabel-variabel yang digunakan dalam penelitian ini menurut Sugiyono (2013: 67) adalah:

a. Variabel terikat (dependent variable) adalah variabel yang dipengaruhi atau menjadi akibat karena adanya variabel lain yaitu motivasi belajar yang dilambangkan dengan Y.

b. Variabel bebas (independent variable) adalah suatu variabel yang menyebabkan atau menjadi sebab bagi berubahnya variabel lain yaitu faktor-faktor yang mempengaruhi motivasi belajar yang dilambangkan dengan $\mathrm{X}$ yang terdiri dari faktor fisik $\left(\mathrm{X}_{1}\right)$, faktor psikologis $\left(\mathrm{X}_{2}\right)$, faktor nonsosial $\left(\mathrm{X}_{3}\right)$ dan faktor sosial $\left(\mathrm{X}_{4}\right)$.

\section{Definisi Operasional Variabel}

\section{a. Faktor Fisik (X1)}

Faktor fisik merupakan faktor yang mempengaruhi dari tubuh dan penampilan individu. faktor fisik meliputi nutrisi (gizi), kesehatan, dan fungsi-fungsi fisik terutama panca indera. Yusuf (2009: 23). Indikator yang digunakan semangat belajar, ngantuk, melihat tulisan jarak jauh dan merasa lapar.

\section{b Faktor Psikologis (X2)}

Faktor psikologis merupakan faktor intrinsik yang berhubungan dengan aspek-aspek yang mendorong atau menghambat aktivitas belajar pada siswa. faktor ini menyangkut kondisi rohani siswa. Yusuf (2009: 23)

\section{c. Faktor Non-Sosial (X3)}

Faktor non-sosial merupakan faktor yang berasal dari keadaan atau kondisi fisik disekitar siswa. Faktor non-sosial Meliputi keadaan udara (cuaca panas atau dingin), waktu (pagi, siang, atau malam), tempat (sepi, bising, atau kualitas sekolah tempat belajar), dan fasilitas belajar (sarana dan prasarana). Yusuf (2009: 23)

\section{d. Faktor Sosial}

Faktor sosial yaitu yang berasal dari manusia sekitar lingkungan siswa. Faktor sosial meliputi guru/ dosen, konselor, teman sebaya, orang tua, teman sebaya, tetangga dan lain-lain. Yusuf (2009: 23)

\section{e. Motivasi}

Motivasi sebagai keseluruhan daya penggerak didalam diri siswa yang menimbulkan kegiatan 
Sulistiowati, S. Martono. 2009. Analisis faktor-faktor yang mempengaruhi motivasi belajar mahasiswa (study kasus di stikom Surabaya). Surabaya. stikom Surabaya.

Sunyoto, Danang. 2013. Manajemen Sumber Daya Manusia. Jakarta: Center for Academic Publishing Service

Sutrisno, Edy. 2013. Manajemen Sumber Daya Manusia, Edisi Pertama, Jakarta : Kencana.

Widiyanto, Joko. 2010. SPSS for windows : untuk analisis data statistik dan penelitian. Surabaya: BP-FKIP UMS.

Yusuf, Syamsu. 2009. Program Bimbingan dan Konseling di Sekolah. Bandung: Rizqi Perss. 